Materiales de Construcción

Vol. 67, Issue 326, April-June 2017, e121

ISSN-L: 0465-2746

http://dx.doi.org/10.3989/mc.2017.08116

\title{
PCE and BNS admixture adsorption in sands with different composition and particle size distribution
}

\author{
M.M. Alonso $\bowtie$, R. Martínez-Gaitero, S. Gismera-Diez, F. Puertas \\ Eduardo Torroja Institute for Construction Sciences (IETcc-CSIC). Madrid-Spain \\ \mmalonso@ietcc.csic.es
}

Received 29 June 2016

Accepted 23 September 2016

Available on line 24 February 2017

\begin{abstract}
The choice of a superplasticiser (SP) for concrete is of great complexity, as it is well known that properties of the end product are related to admixture and its compatibility with concrete components. Very few studies have been conducted on the compatibility between SPs and the sand of mortars and concretes, however. Practical experience has shown that sand fineness and mineralogical composition affect water demand and admixture consumption. Clay-containing sand has been found also to adsorb SPs, reducing the amount available in solution for adsorption by the cement. This study analysed the isotherms for PCE and BNS superplasticiser adsorption on four sands with different fineness and compositions commonly used to prepare mortars and concretes. BNS-based SP did not adsorb on sands, while PCE-based admixtures exhibited variable adsorption depending on different factors. The adsorption curves obtained revealed that the higher the sand fineness, the finer the particle size distribution and the higher the clay material, the greater was PCE admixture adsorption/ consumption.
\end{abstract}

KEYWORDS: Sand; Superplasticizer; Clay; Fineness; Compatibility

Citation/Citar como: Alonso, M.M.; Martínez-Gaitero, R.; Gismera-Diez, S.; Puertas, F. (2017) PCE and BNS admixture adsorption in sands with different composition and particle size distribution. Mater. Construcc. 67 [326], e121 http://dx.doi.org/10.3989/mc.2017.08116

RESUMEN: Adsorción de aditivos PCE y BNS en arenas con diferente composición y distribución de tamaño de partículas. La elección de un superplastificante (SP) para el hormigón es un proceso complejo, ya que las propiedades del producto final se relacionan con la naturaleza del aditivo y su compatibilidad con los componentes del hormigón. Sin embargo hay pocos estudios sobre la compatibilidad entre los SPs y arenas utilizadas en morteros y hormigones. En la práctica se ha demostrado que la finura y la composición mineralógica de la arena afectan a la demanda de agua y al consumo de SPs. Las arcillas que pueden encontrarse en las arenas pueden también adsorber aditivos, reduciendo la cantidad disponible en solución para la adsorción por el cemento. Se han analizado las isotermas de adsorción para SPs de tipo PCE y BNS en cuatro arenas de diferente finura y composicion comúnmente utilizado para preparar morteros y hormigones. El aditivo BNS no se adsorbe en las arenas, mientras que los PCE mostraron adsorción variable. Las curvas de adsorción revelaron que cuanto mayor es la finura de arena, menor la distribución del tamaño de partícula y mayor el contenido de arcilla mayor era adsorción/intercalación de aditivos PCE en las arenas.

Palabras clave: Arena; Superplastificante; Arcilla; Finura; Compatibilidad

ORCID ID: M.M.Alonso (http://orcid.org/0000-0001-9096-752X); R. Martinez-Gaitero (http://orcid.org/0000-00017296-0850); S. Gismera-Diez (http://orcid.org/0000-0002-4094-2997); F. Puertas (http://orcid.org/0000-0002-4215-0184)

Copyright: (C 2017 CSIC. This is an open-acces article distributed under the terms of the Creative Commons Attribution License (CC BY) Spain 3.0. 


\section{INTRODUCTION}

The use of superplasticisers (SPs) is known to have favoured concrete technological development, although practical experience has shown that admixtures do not always have the fluidising effect expected, often due to incompatibility between the SP and the concrete components (1-3). Admixturerelated factors such as formulation and structure, molecular weight, charge density and ether chain length, together with cement characteristics such as $\mathrm{C}_{3} \mathrm{~A}$, sulfate and alkali content, fineness, the presence of additions and mineralogical composition, are known to impact compatibility (4-13).

Concrete manufacture involves other components, however, including sand (fine aggregate) and coarse aggregate, whose fineness and composition also determine the properties of the end product $(14,15)$. Concrete performance as well as its water and admixture demand vary with the nature and particle size composition of the aggregate (14, 16-18). The presence of clay in sand, for instance, has been shown to reduce superplasticiser effectiveness due to admixture intercalation by the clay $(1,19)$, a development that depends on the type of admixture and the nature of the clay and its cation exchange capacity (20-22). Naphthalene derivativebased admixtures (BNS) appear to be more resistant or less susceptible to interlayering in the clay than their Polycarboxylate ether admixtures (PCE) counterparts $(1,23,24)$. Only surface adsorption takes place in naphthalene admixtures, whereas PCEs are chemisorbed and intercalated in the clay in a process essentially involving their PEO side chains $(20,25)$. A number of new PCE formulations (with hydroxy alkyl side chains) without PEO lateral chains, have proven to be less prone to clay intercalation $(25,26)$.

The clay with the most adverse effect on PCE fluidising behaviour is montmorillonite, followed by kaolinite and muscovite in that order $(20,27)$. Moreover, the interaction of admixtures with montmorillonite depends on the charge compensation cations in their structure $\left(\mathrm{Na}^{+}, \mathrm{Mg}^{2+}\right.$ or $\left.\mathrm{Ca}^{2+}\right)$. AitAkbour et al. (21) showed that polycarboxylate poly(ethylene glycol) (PCP) esters admixtures were interlayered in the presence of $\mathrm{Na}^{+}$, adsorbed on the surface in the presence of $\mathrm{Ca}^{2+}$ and interlayered and adsorbed both in the presence of $\mathrm{Mg}^{2+}$.

Some authors $(28,29)$, studying the effect of sand particle size distribution on the water demand and fluidity of concrete, observed that the demand for admixture rose when the sand used had higher proportions of fines. Nonetheless, very few studies have broached the overall interaction between different types of sands and superplasticisers, focusing particularly on admixture adsorption. This study consequently explored the adsorption of two types of superplasticisers (PCE and BNS) on sands commonly used in concrete manufacture but differing in composition, surface area and particle size distribution.

\section{EXPERIMENTAL}

\subsection{Solid materials}

Four sands with different compositions, labelled $\mathrm{A}, \mathrm{B}, \mathrm{C}$ and $\mathrm{D}$, and cement CEM I 52,5R (CEM I) were used in this study.

\subsubsection{Chemical analyses}

The chemical composition of the sands and the cement was determined on a PHILIPS PW-1004 X-ray fluorescence (XRF) spectrophotometer. Loss on ignition was found as specified in the applicable standard (30). The findings are given in Table 1.

\subsubsection{Mineralogical analysis}

The sands were characterised for mineralogy on a Bruker AXS D8 Advance X-ray diffractometer and the results were quantified using the Rietveld method. In addition, infrared spectra were recorded for all the samples in $\mathrm{KBr}$-compressed wafers on a Nicolet 6700 Fourier transform infrared spectroscope. The X-ray diffractograms and FTIR spectra for the sands are reproduced in Figures 1 and 2, respectively.

The diffractograms showed, firstly, that whereas the minerals comprising sands $\mathrm{A}$ and B were nearly entirely crystalline, sands $C$ and $\mathrm{D}$ exhibited a halo (larger in sand D), indicative of the presence of amorphous material. Quartz was the main crystalline phase in sand $\mathrm{A}$, which

TABLE 1. Chemical composition ( $\mathrm{wt}^{\%} \%$ ) of the sands and cement studied

\begin{tabular}{|c|c|c|c|c|c|}
\hline Oxide & Sand A & Sand B & Sand C & Sand D & CEM I \\
\hline $\mathrm{SiO}_{2}$ & 96.80 & 89.27 & 76.20 & 65.73 & 18.90 \\
\hline $\mathrm{Al}_{2} \mathrm{O}_{3}$ & 1.51 & 5.41 & 12.90 & 15.20 & 4.41 \\
\hline $\mathrm{K}_{2} \mathrm{O}$ & 0.56 & 3.21 & 5.02 & 3.68 & 0.82 \\
\hline $\mathrm{Na}_{2} \mathrm{O}$ & - & 0.88 & 3.87 & 3.37 & 0.10 \\
\hline $\mathrm{Fe}_{2} \mathrm{O}_{3}$ & 0.43 & 0.20 & 0.72 & 3.58 & 3.91 \\
\hline $\mathrm{CaO}$ & 0.10 & 0.13 & 0.41 & 3.55 & 63.22 \\
\hline $\mathrm{MgO}$ & - & - & - & 1.23 & 1.68 \\
\hline $\mathrm{TiO}_{2}$ & - & - & - & 0.56 & 0.25 \\
\hline $\mathrm{P}_{2} \mathrm{O}_{5}$ & - & - & - & 0.18 & - \\
\hline $\mathrm{SO}_{3}$ & - & - & - & - & 3.30 \\
\hline $\mathrm{Rb}_{2} \mathrm{O}$ & - & - & 0.06 & - & - \\
\hline $\mathrm{Mn}_{2} \mathrm{O}_{3}$ & & & & & $<0.1$ \\
\hline $\mathrm{Cr}_{2} \mathrm{O}_{3}$ & & & & & $<0.1$ \\
\hline $\mathrm{ZnO}$ & & & & & $<0.1$ \\
\hline LoI & 0.61 & 0.90 & 0.70 & 2.80 & 3.15 \\
\hline
\end{tabular}

LoI: Loss on Ignition. 

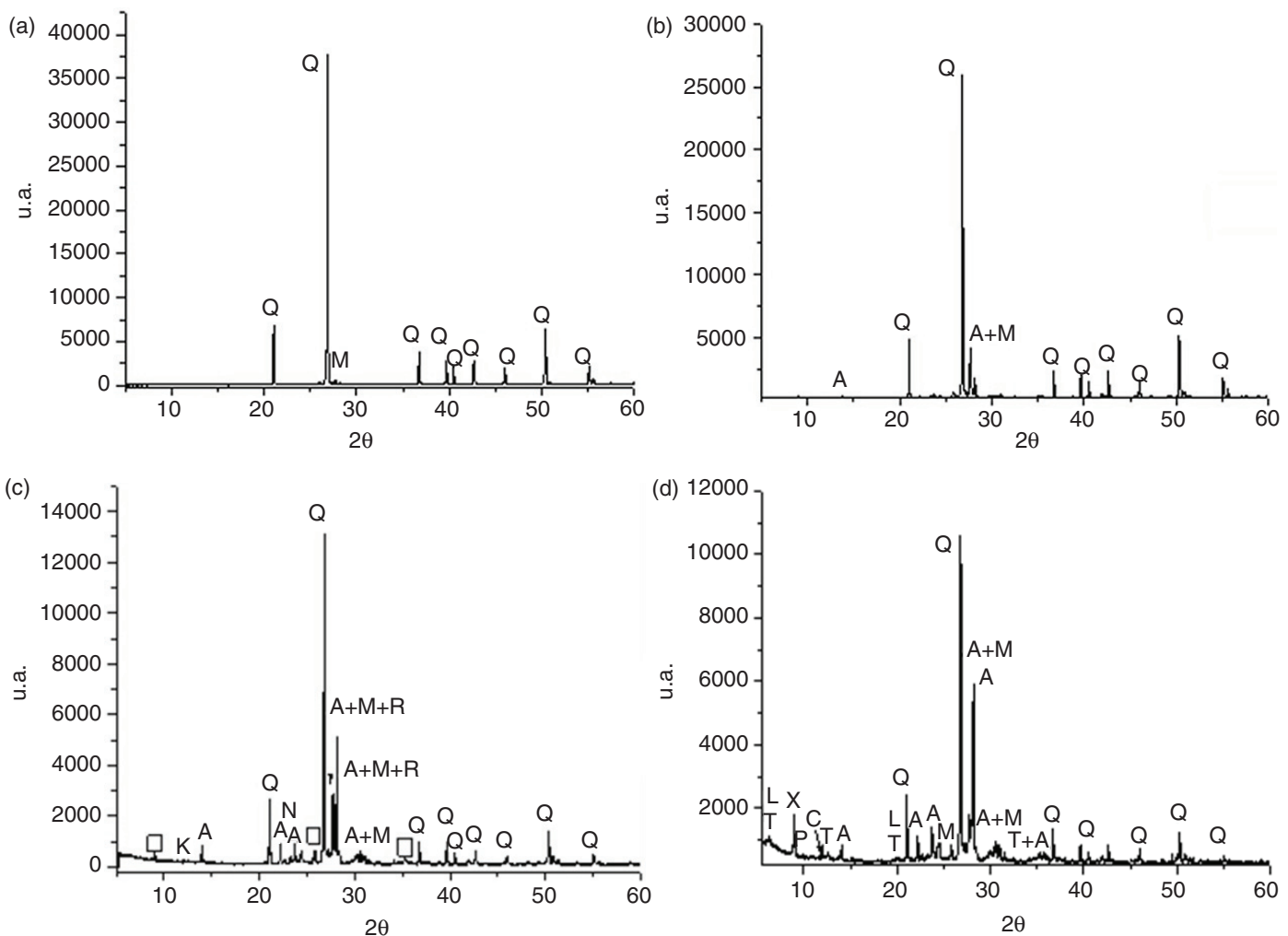

FiguRE 1. Diffractograms of the sands used. Legend: Q, quartz; M, microcline; $\square$ muscovite; K, kaolinite; A, albite; N, anorthite; $\mathrm{R}$, rubidium silicoaluminate; C, Cordierite; L, Chlorite; T, Montmorillonite; X, phlogopite; $\mathrm{P}, \mathrm{NaTiH}\left(\mathrm{PO}_{4}\right)_{2} \cdot \mathrm{H}_{2} \mathrm{O}$.

also contained traces of microcline $\left(\mathrm{KAlSi}_{3} \mathrm{O}_{8}\right)$. In addition to quartz and microcline, sand $\mathrm{B}$ had traces of albite $\left(\mathrm{NaAlSi}_{3} \mathrm{O}_{8}\right)$. Sand $\mathrm{C}$ comprised the aforementioned phases as well as anorthite $\left(\mathrm{CaAl}_{2} \mathrm{Si}_{2} \mathrm{O}_{8}\right)$, a rubidium silicoaluminate $\left(\mathrm{RbAlSiO}_{4}\right)$, muscovite $\left(\mathrm{KAl}_{2}\left(\mathrm{AlSi}_{3} \mathrm{O}_{10}\right)\right.$ $\left.(\mathrm{OH})_{2}\right)$ and kaolinite $\left(\mathrm{Al}_{2} \mathrm{Si}_{2} \mathrm{O}_{5} \cdot(\mathrm{OH})_{4}\right)$, the latter two being characteristic of the presence of clay. Sand D exhibited quartz, microcline, albite and was the only fine aggregate that contained $\mathrm{NaTiH}\left(\mathrm{PO}_{4}\right) 2 \cdot \mathrm{H}_{2} \mathrm{O}$, phlogopite $\left(\mathrm{KMg}_{3}\left(\mathrm{FeSi}_{3} \mathrm{O}_{10}\right)\right.$ $(\mathrm{OH})_{2}$, cordierite $\left((\mathrm{Mg}, \mathrm{Fe})_{2} \mathrm{Al}_{4} \mathrm{Si}_{5} \mathrm{O}_{18}\right)$, chlorite $(\mathrm{Mg}, \mathrm{Fe})_{3}(\mathrm{Si}, \mathrm{Al})_{4} \mathrm{O}_{10} \quad(\mathrm{OH})_{2} \cdot(\mathrm{Mg}, \mathrm{Fe})_{3}(\mathrm{OH})_{6}$ and montmorillonite $\left(\mathrm{NaAl}_{2} \mathrm{Si}_{5} \mathrm{O}_{14} \cdot \mathrm{xH}_{2} \mathrm{O}\right)(31,32)$.

The quantitative mineralogical composition of the sands yielded by Rietveld analysis is given in Table 2.

The FTIR spectrum for sand A exhibited characteristic bands at around 1165, 1083 and $1004 \mathrm{~cm}^{-1}$ induced by the asymmetrical $\mathrm{Si}-\mathrm{O}$ vibrations in quartz, and a likewise characteristic double band at wave numbers 797 and $778 \mathrm{~cm}^{-1}$, along with bands at around 690 and $462 \mathrm{~cm}^{-1}$, also from quartz $(30,32)$. These bands were clearly visible on the spectra for sands $B, C$ and $D$ as well. In addition, the spectra for sands $\mathrm{A}$ and $\mathrm{B}$ exhibited a signal centred at around $669 \mathrm{~cm}^{-1}$ and a second in $\mathrm{B}$ only at $731 \mathrm{~cm}^{-1}$, both induced by $\mathrm{Al}-\mathrm{O}$ bond asymmetrical stretching vibrations in the $\mathrm{AlO}_{4}$ groups present in microcline, albite or both. Lastly, the IR spectrum for sand A contained a band at $940 \mathrm{~cm}^{-1}$ attributable to the Al-O bond vibrations in microcline. In addition, overlapping and fairly intense absorption bands at around 1140,1041 and $1012 \mathrm{~cm}^{-1}$, characteristic of T-O and Si-O-T $(\mathrm{T}=\mathrm{Si}, \mathrm{Al})$ bond vibrations, were observed on the IR spectra for sands C and D. This, which could be attributed to the overlapping among the adsorption bands generated by the many mineralogical phases present in the aggregate (such as quartz, microcline and albite), rendered the differentiation of each mineral's specific frequencies difficult.

Lastly, the IR spectra for sands C and D exhibited bands at around 536 and $518 \mathrm{~cm}^{-1}$ characteristic of Si-O-Al bond vibrations, and at $428 \mathrm{~cm}^{-1}$, assigned to the Si-O bond in albite $(31,33,34)$.

\subsubsection{Physical and surface analysis}

The moisture, water adsorption and density determined for each sand as specified in the applicable European standard are given in Table 3 (35). The table also lists the Blaine fineness for CEM I $\left(425 \mathrm{~m}^{2} / \mathrm{kg}\right)$ and the BET specific surface for the sands determined on a Micromeritics TriStar 3000 analyser.

Sand particle size distribution as found by differential sieving is shown in Figure 3 and Table 4. 

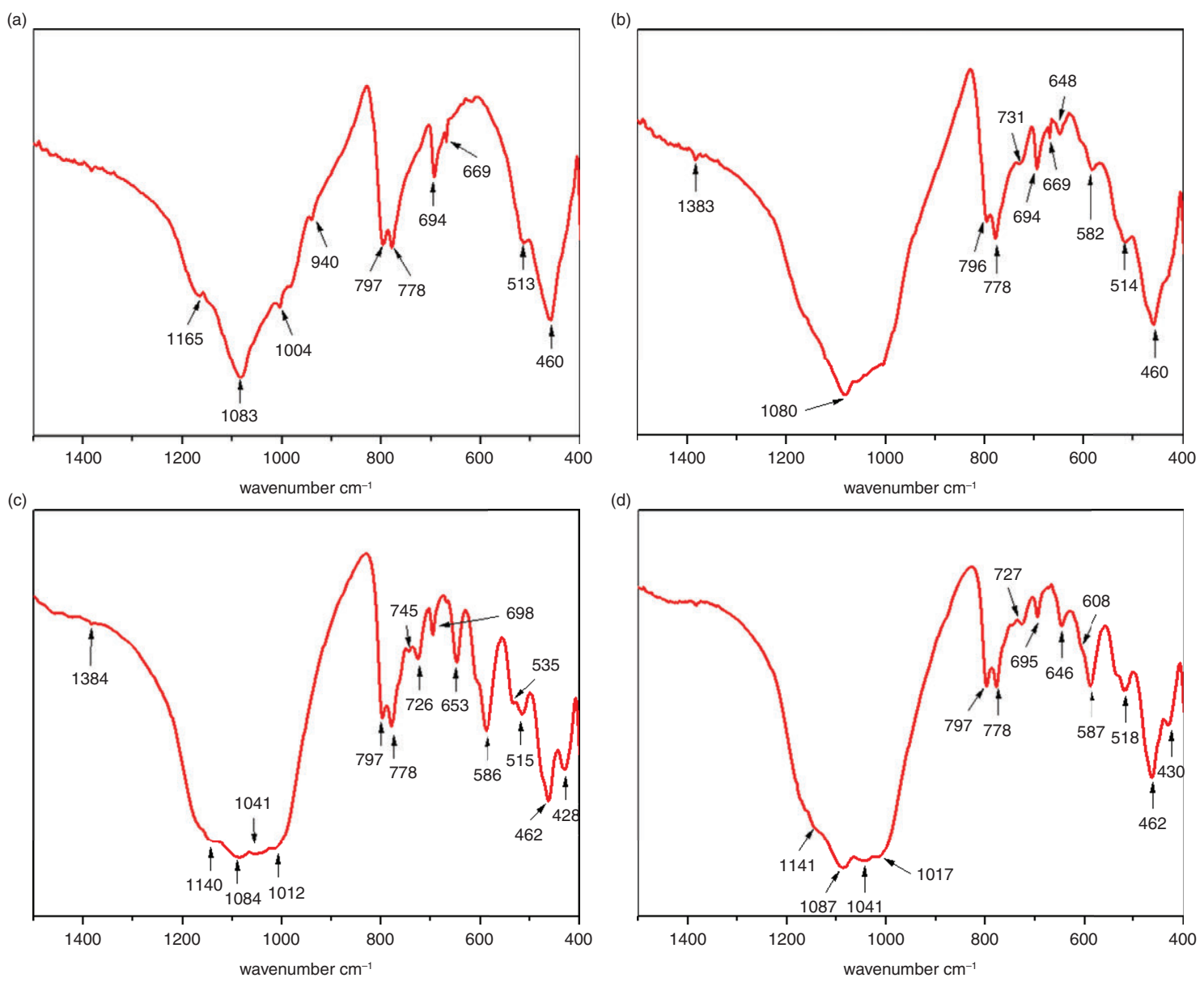

FIGURE 2. FTIR spectra for the sands studied.

TABLE 2. Quantitative mineralogical composition of sand $(\mathrm{wt} \%)$

\begin{tabular}{lrrrc}
\hline Mineralogical phase & A & B & C & D \\
\hline Quartz & 98.3 & 66.1 & 28.7 & 20.4 \\
Microcline & 1.7 & 26.5 & 18.9 & 26.0 \\
Albite & - & 7.4 & 35.9 & 33.5 \\
Anorthite & - & - & 8.3 & - \\
Rubidium silicoaluminate & - & - & 2.2 & - \\
Muscovite & - & - & 4.0 & - \\
Kaolinite & - & - & 1.9 & - \\
Chlorite & - & - & - & 5.8 \\
Phlogopite & & & & 13.3 \\
NaTiH $\left(\mathrm{PO}_{4}\right)_{2} \cdot \mathrm{H}_{2} \mathrm{O}$ & & & & $<0.1$ \\
Cordierite & & & & $<0.1$ \\
Montmorillonite & & & & 0.8
\end{tabular}

\subsection{Superplasticisers}

Two superplasticisers were used: one based on polycarboxylate ethers (PCE) and the other on naphthalene (BNS). PCE admixture has a high
TABLE 3. Physical characteristics of the sands studied

\begin{tabular}{lcccc}
\hline & Sand A & Sand B & Sand C & Sand D \\
\hline Moisture (\%) & 0.07 & 0.04 & 1.89 & 4.56 \\
Water absorption (\%) & 0.08 & 0.24 & 0.22 & 0.34 \\
Density (g/L) & 2.64 & 2.61 & 2.50 & 2.60 \\
BET sp. surface $\left(\mathrm{m}^{2} / \mathrm{g}\right)$ & 0.44 & 1.10 & 1.38 & 4.46 \\
\hline
\end{tabular}

side chain length and it is commonly used for precast concrete application. Their main physical and chemical characteristics are listed in Table 5. Their dry extracts were determined as European standard EN 480-8-1997 (36) and elemental analysis was conducted on a CHNS PERKIN ELMER 2400 analyser.

\subsection{Tests conducted}

- Determination of PCE and BNS adsorption isotherm on CEM I and sand in suspension: $20 \mathrm{~g}$ of cement or $10 \mathrm{~g}$ of sand were mixed with $40 \mathrm{~g}$ of a water solution containing PCE or BNS and stirred for 30 minutes at $25^{\circ} \mathrm{C}$. The suspensions 


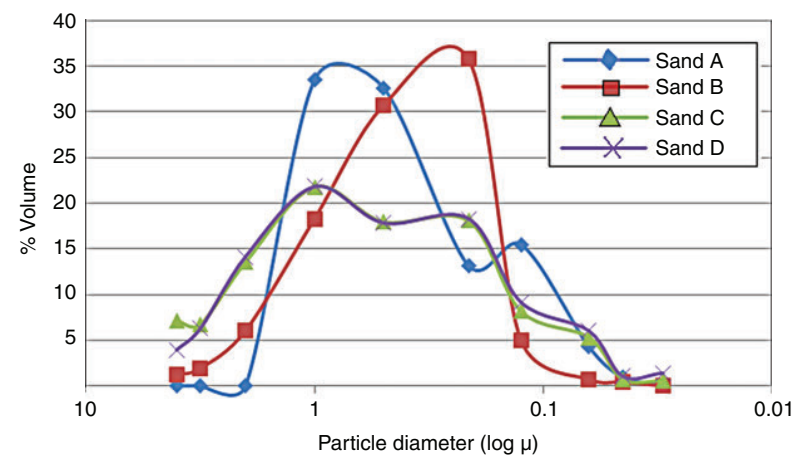

Figure 3. Particle size distribution in sands A, B, C and D.

TABLE 4. Particle size distribution of the sands studied

\begin{tabular}{lcccc}
\hline & \multicolumn{4}{c}{$\%$ retained } \\
\cline { 2 - 5 } Sieve (mm) & Sand A & Sand B & Sand C & Sand D \\
\hline 4 & & 1.20 & 7.17 & 3.96 \\
3.15 & & 1.93 & 6.74 & 6.29 \\
2 & & 6.06 & 13.52 & 14.15 \\
1 & 33.47 & 18.26 & 21.77 & 21.80 \\
0.5 & 32.64 & 30.66 & 17.94 & 17.84 \\
0.212 & 13.17 & 35.73 & 18.06 & 18.31 \\
0.125 & 15.48 & 5.00 & 8.18 & 9.16 \\
0.063 & 4.27 & 0.73 & 5.31 & 6.02 \\
0.045 & 0.97 & 0.43 & 0.74 & 1.06 \\
$<0.045$ & - & - & 0.58 & 1.42 \\
\hline
\end{tabular}

TABLE 5. Physical-chemical characteristics of the superplasticisers studied

\begin{tabular}{lrc}
\hline & PCE & BNS \\
\hline Solids content (\%) & 53.80 & 39.60 \\
Average molecular weight (Mw) (D) & 38500 & 137000 \\
Side chain length & 5800 & - \\
Charge density & High & - \\
Carbon & 51.08 & 45.15 \\
Hydrogen & 8.99 & 4.53 \\
Sulfur & 1.53 & 8.83 \\
Oxygen & 38.38 & 41.46 \\
\hline
\end{tabular}

were then ultra-centrifuged during $30 \mathrm{~min}$ at $3000 \mathrm{rpm}$, and the liquid phase was poured off to determine the total organic carbon content. This analysis was conducted on a TOC Shimadzu $\mathrm{CSH} / \mathrm{CSN}$ analyser fitted with an infrared detector and platinum catalyst and using synthetic air as the carrier gas. Admixture adsorption was taken to be the difference between the amount initially added to the mix and the amount measured in the liquid phase (10).
TABLE 6. Ionic composition and $\mathrm{pH}$ of the cement pore solution

\begin{tabular}{ll}
\hline & Mol/L \\
\hline $\mathrm{Ca}^{2+}$ & 0.012 \\
$\mathrm{Na}^{+}$ & 0.276 \\
$\mathrm{SO}_{4}^{2-}$ & 0.1 \\
$\mathrm{OH}^{-}$ & 0.1 \\
$\mathrm{pH}$ & 12.75 \\
\hline
\end{tabular}

- Determination of PCE adsorption isotherm on different sand particle size fractions: the four fractions studied were: $>2000 \mu \mathrm{m}, 2000-$ $500 \mu \mathrm{m}, 500-125 \mu \mathrm{m}$ and $<125 \mu \mathrm{m}$.

- Determination of PCE adsorption isotherm on $10 \mathrm{~g}$ of sand in an cement pore solution prepared as specified in the literature (37). The composition of the cement pore solution is given in Table 6

The plateau values for each adsorption curve were found by exponential fitting of the data, further to earlier research $(38,39)$.

- Determination of fluidity of cement mortars with PCE $(0.2 \%$ weight of cement) and BNS admixtures $(1.2 \%$ weight of cement). Cement mortars (prepared as UNE EN 196-1) (40) with and without admixtures with cement/sand ratio $=1$ were prepared to ensure similar consistency. Fluidity without and with admixtures were tested according with cone test (41).

\section{RESULTS AND DISCUSSION}

\subsection{Adsoption isotherms for CEM I and sands in water}

Figures $4 \mathrm{a}$ and $4 \mathrm{~b}$ reproduce the isotherms for PCE and BNS adsorption on CEM I and sands A, $\mathrm{B}, \mathrm{C}$ and $\mathrm{D}$ in water, and also show the adsorption plateau values for each curve.

A comparison of Figures $4 \mathrm{a}$ and $4 \mathrm{~b}$ reveals very distinct differences in admixture consumption on both CEM I and the sands, depending essentially on the composition and structure of both the admixture and the substrate. Seventy per cent less PCE than BNS was adsorbed by CEM I (plateau values $=5.99$ and $19.40 \mathrm{mg}$ polymer/g cement, respectively). These results are consistent with earlier findings, according to which cement adsorbed BNS and PMS (melanin derivative) admixtures more readily than polycarboxylate ether-based superplasticisers $(11,42,43)$.

Considerable differences in PCE and BNS consumption on sand were also observed. Inasmuch as the features that distinguished the sands were their fineness, particle size distribution and chemical 

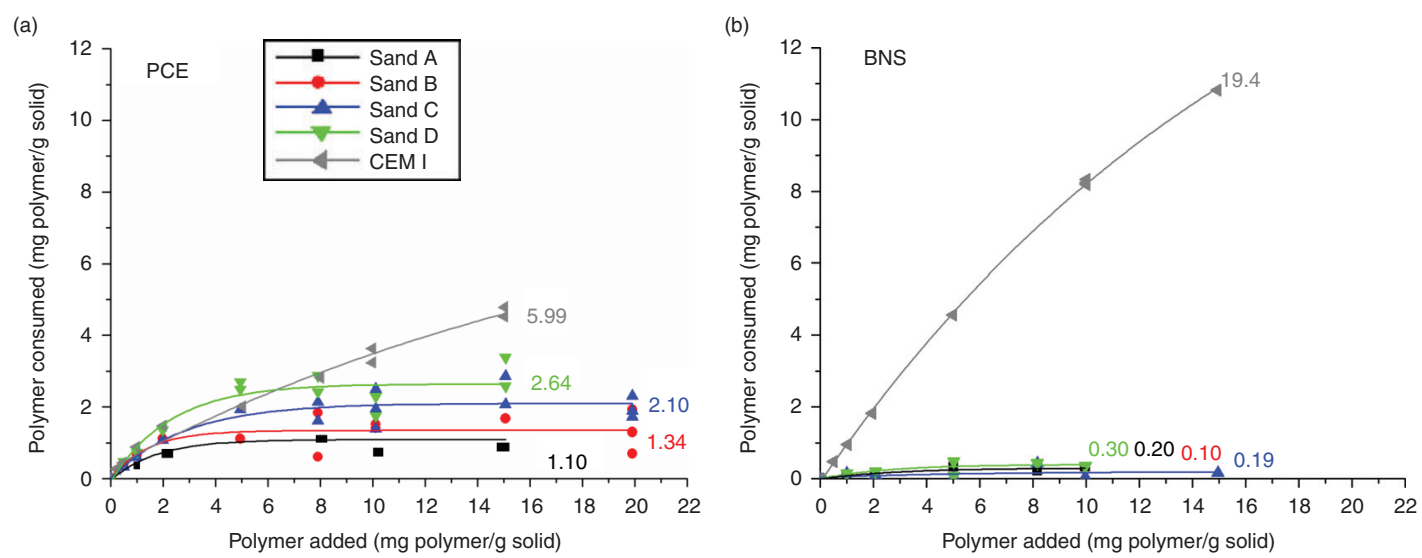

FIgURE 4. Isotherms for a) PCE and b) BNS consumption on CEM I and sands A, B, C and D.

composition. The discussion below is organised around the factors that appear to affect consumption: admixture composition and structure, and sand specific surface, particle size distribution and mineralogy.

\section{a) Admixture composition and structure}

Figures $4 \mathrm{a}$ and $4 \mathrm{~b}$ reveal differences in PCE and BNS consumption on the sands studied. Their consumption patterns were the reverse of the patterns found for CEM I. The BNS-based admixture adsorbed on the sand either barely or not at all, exhibiting no significantly differential behaviour with changes in the composition or particle size distribution of the substrate. PCE consumption values, in contrast, were clearly higher than BNs ones, and differed visibly depending on the sand. These findings showed that admixture composition is a determinant key for consumption not only on cements and its additions, but also on different types of sand.

\section{b) Sand specific surface}

One of the fundamental differences among the sands studied here was their BET specific surface (Table 3 ). In cements and additions, a higher specific surface and consequently greater fineness has been shown to raise the amount of admixture adsorbed $(11,39,44)$.

Admixture PCE consumption (Figure 4a) was observed to rise from sand $\mathrm{A}$ to sand $\mathrm{D}$, albeit non-linearly, with the BET values of the substrate (Figure 5). Nonetheless, in sands $\mathrm{B}$ and $\mathrm{C}$, with very similar BET values $\left(1.10\right.$ and $1.38 \mathrm{~m}^{2} / \mathrm{g}$, respectively: Table 3 ), the degree of admixture adsorption/consumption varied widely (1.34 and $2.10 \mathrm{mg}$ polymer/g solid, respectively). The obviously nonlinear relationship between the BET area and admixture consumption observed in Figure 5 attests to the existence of other factors, including sand particle size distribution, that affected the plateau value.

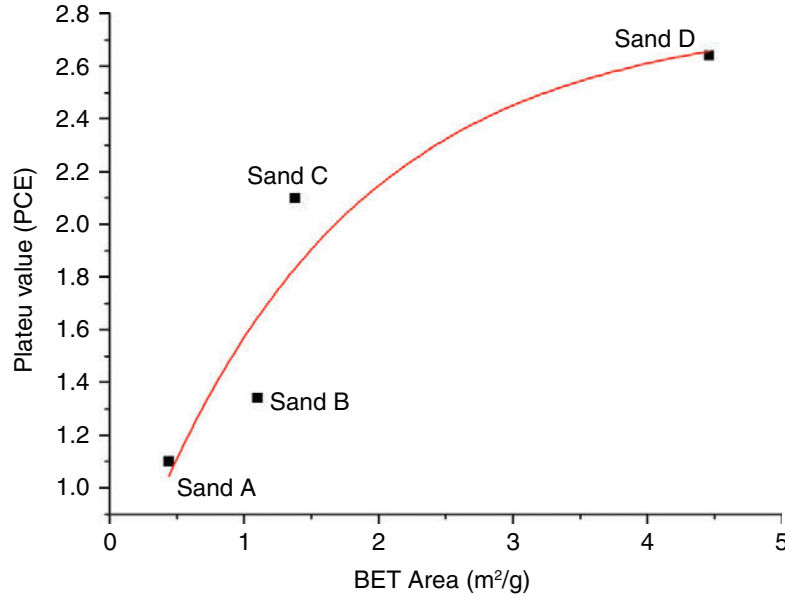

FIGURE 5. PCE adsorption values on sand versus sand BET area.

\section{c) Sand particle size distribution}

The isotherms in Figures $6 a, 6 b, 6 c$ and $6 d$, showing PCE adsorption on the fractions of sand specified above, were used to analyse the relevance of sand fineness and particle size distribution in admixture adsorption.

The theoretical overall plateau value for each sand was computed from the adsorption data for each fraction and the fraction's percentage by weight to verify the validity of the isotherms recorded and reproduced in Figure 6. The results listed in Table 7 confirm the suitability and accuracy of the experimental results.

Both Figure 6 and Table 7 show that the finest fractions in all the sands (the ones with the highest specific surface) adsorbed the most PCE. The plateau values for all the particle size fractions also exhibited the same ascending order as for the sand overall, i.e., $\mathrm{A}<\mathrm{B}<\mathrm{C}<\mathrm{D}$.

The percentage by weight for each fraction and the percentage of overall adsorption accounted for, 
along with the respective plateau value or admixture consumption per sand fraction (red line, in Figure 7), were also found (and shown in Figure 7) to assess the weight of each fraction in overall adsorption and compare the findings in each sand and among sands.

An analysis of Figures 6 and 7 and Table 7 revealed that sand particle size distribution is determinant in PCE adsorption and that, generally speaking, the smaller the sand particle the greater is its affinity for the admixture. Moreover, in all the sands, the proportion of admixture adsorbed by the largest two fractions $(2000$ and 2000$500 \mu \mathrm{m})$ was smaller than their respective percentage by weight in the sample as a whole. That effect was particularly visible in the $>2000-\mu \mathrm{m}$ fraction in sand $\mathrm{B}$, which adsorbed practically no superplasticiser.

Other findings included the following.

- Despite having the finest overall particle size, sand A adsorbed the smallest amount of admixture (1.10 mg polymer/g sand), a finding nonetheless consistent with its lower BET area $(0.44 \mathrm{~m} 2 / \mathrm{g})$ (see Table 4). The finest fraction
$(<125 \mu \mathrm{m})$ accounted for $5 \%$ of the total weight and $9 \%$ of all the PCE adsorbed.

- Adsorption was only slightly higher in sand B (1.38 mg polymer/g sand) than in sand A (1.10 $\mathrm{mg}$ polymer/g sand), despite its threefold higher BET specific surface (1.10 vs 0.44 $\mathrm{m}^{2} / \mathrm{g}$ ), due primarily to its coarser particle size distribution. The presence of particles of over $2 \mathrm{~mm}$, accounted for a very small proportion of overall adsorption, with a value of just $0.18 \mathrm{mg}$ polymer/g sand. Moreover, the fraction under 125 microns in sand B appeared to account for a significant proportion of total adsorption and exhibited a much higher value $(3.15 \mathrm{mg}$ polymer/g sand) than the same fraction in sand A (1.80 mg polymer/g sand), despite the substantially smaller percentage of particles in that range in sand B $(1.16 \%)$ than in sand A $(5.24 \%$, Table 7).

- The plateau value in sand C was 90 and $52 \%$ higher than in sands A and B, respectively. The adsorption values for the particle size fractions in sand $\mathrm{C}$ were likewise higher than the respective values for sands $\mathrm{A}$ and $\mathrm{B}$. These findings were particularly significant, inasmuch
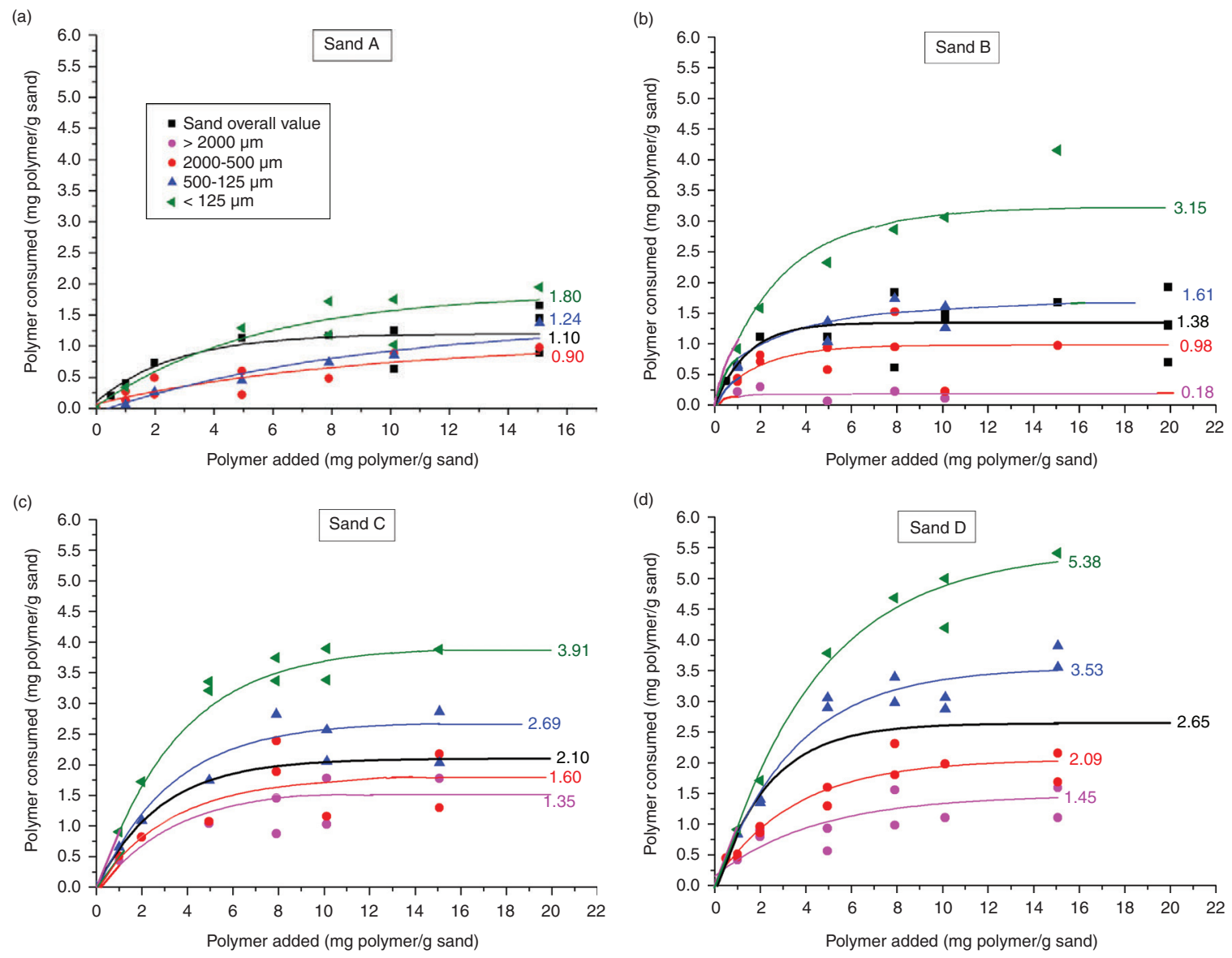

FIGURE 6. PCE adsorption on different particle size fractions: sands A, B, C and D. 
TABLE 7. PCE adsorption on sand particle size fractions

\begin{tabular}{|c|c|c|c|c|}
\hline Sand & Fraction & Fraction weight $(\%)$ & Plateau value (mg polymer/g sand) & $\begin{array}{l}\text { Theoretical overall plateau value } \\
\text { (mg polymer/g sand) }\end{array}$ \\
\hline \multirow[t]{5}{*}{ A } & $>2000 \mu \mathrm{m}$ & - & - & \\
\hline & $2000-500 \mu \mathrm{m}$ & 66.11 & 0.90 & \\
\hline & $500-125 \mu \mathrm{m}$ & 28.65 & 1.24 & \\
\hline & $>125 \mu \mathrm{m}$ & 5.24 & 1.80 & \\
\hline & Experimental overall value & $100 \%$ & 1.10 & 1.04 \\
\hline \multirow[t]{5}{*}{ B } & $>2000 \mu \mathrm{m}$ & 9.19 & 0.18 & \\
\hline & $2000-500 \mu \mathrm{m}$ & 48.92 & 0.98 & \\
\hline & $500-125 \mu \mathrm{m}$ & 40.73 & 1.61 & \\
\hline & $>125 \mu \mathrm{m}$ & 1.16 & 3.15 & \\
\hline & Experimental overall value & $100 \%$ & 1.38 & 1.20 \\
\hline \multirow[t]{5}{*}{$\mathrm{C}$} & $>2000 \mu \mathrm{m}$ & 27.43 & 1.35 & \\
\hline & $2000-500 \mu \mathrm{m}$ & 39.41 & 1.60 & \\
\hline & $500-125 \mu \mathrm{m}$ & 26.24 & 2.69 & \\
\hline & $>125 \mu \mathrm{m}$ & 6.63 & 3.91 & \\
\hline & Experimental overall value & $100 \%$ & 2.10 & 2.04 \\
\hline \multirow[t]{5}{*}{$\mathrm{D}$} & $>2000 \mu \mathrm{m}$ & 24.40 & 1.45 & \\
\hline & $2000-500 \mu \mathrm{m}$ & 39.64 & 2.09 & \\
\hline & $500-125 \mu \mathrm{m}$ & 27.47 & 3.53 & \\
\hline & $>125 \mu \mathrm{m}$ & 8.50 & 5.38 & \\
\hline & Experimental overall value & $100 \%$ & 2.65 & 2.61 \\
\hline
\end{tabular}

(a)

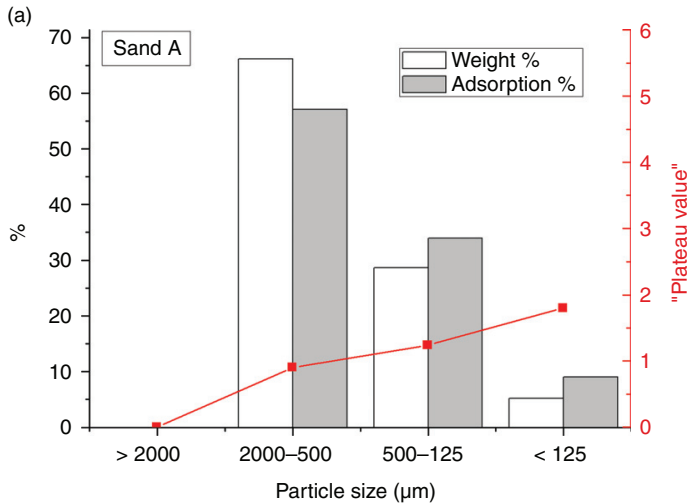

(c)

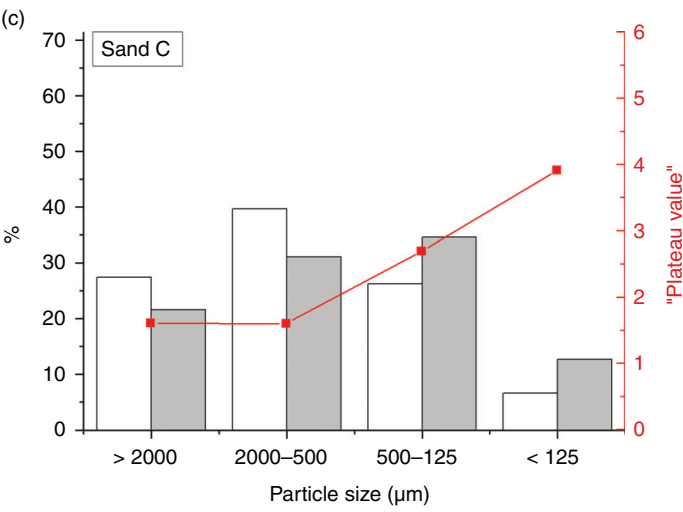

(b)

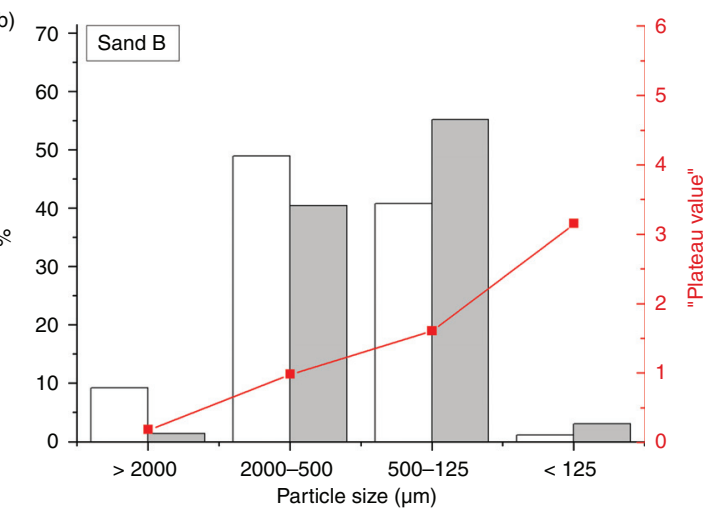

(d)

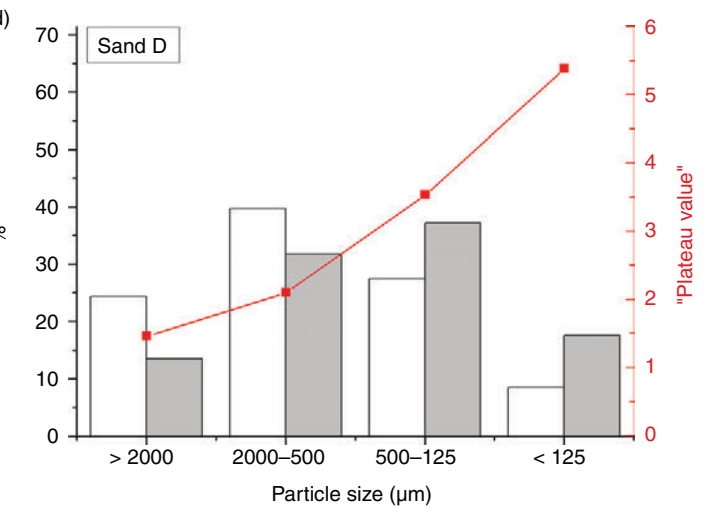

FIGURE 7. Percentage of particle size fraction versus PCE adsorption. 
as sand $\mathrm{C}$ had a much coarser particle size than sands A and B (Table 4 and Figure 3 ) and a specific surface $\left(1.38 \mathrm{~m}^{2} / \mathrm{g}\right)$ similar to the BET area in sand B $\left(1.10 \mathrm{~m}^{2} / \mathrm{g}\right)$. Consequently, as the higher adsorption observed in this sand was not justified either by its particle size distribution or its BET area, it must have been due to the differences in its composition, i.e., to the clayey materials able to adsorb admixtures on or interlayer them into their structure $(1,20,25,27)$.

- $\quad$ Sand D adsorbed more admixture PCE than any of the other three. The most visible differences between sands $\mathrm{C}$ and $\mathrm{D}$ were the much higher values in the two smallest particle size fractions (500-125 and $<125 \mu \mathrm{m}$ ) in the latter. More specifically, the plateau value for admixture PCE in the under $125-\mu \mathrm{m}$ fraction in sand $\mathrm{D}$ was much greater $(5.38 \mathrm{mg}$ polymer/g sand) than the analogous value in sand $C$ (3.91 mg polymer/g sand). Furthermore, as in sand $\mathrm{C}$, both the coarsest $(>2000 \mu \mathrm{m})$ and the intermediate (2000-500 and $500-125 \mu \mathrm{m})$ fractions accounted for a fair proportion of overall adsorption. These findings were likewise significant, given the similarity in the particle size fraction/proportion of adsorption profiles (Figures $7 \mathrm{c}$ and $7 \mathrm{~d}$ ) for sands $C$ and $D$. The inference is that in these fractions the differences in adsorption appeared to be related to the mineralogical differences between the two sands.

\section{d) Chemical and mineralogical composition of the sands}

The quartz content of each sand was plotted against its plateau value (Figure 8) to determine whether, as the preliminary findings appeared to indicate, the sand mineralogy was a significant variable.

First of all, Figure 8 reveals that sand D is the one with lower quartz content and therefore higher clay content, which explains its high BET surface $\left(4.46 \mathrm{~m}^{2} / \mathrm{g}\right)$ (Table 3$)$.

The figure shows that the lower the quartz or the higher the clay content in a sand, the higher was its admixture consumption due to its adsorption on or intercalation in the clay (20).

Overall and fraction-by-fraction adsorption was greater in sand C and D than in any of the others. That behaviour would be explained by the greater clay content (specially in fractions $<125 \mu \mathrm{m}$ ) in these sands and the presence of montmorillonite in sand D, which has been shown to have a greater capacity to intercalate admixtures among its layers $(20,21)$. In order to check this hypothesis, Rietveld analysis of the fine fractions $(<125 \mu \mathrm{m})$ of sands $\mathrm{C}$ and $\mathrm{D}$ were performed. Results are shown in Figure 9 and Table 8.

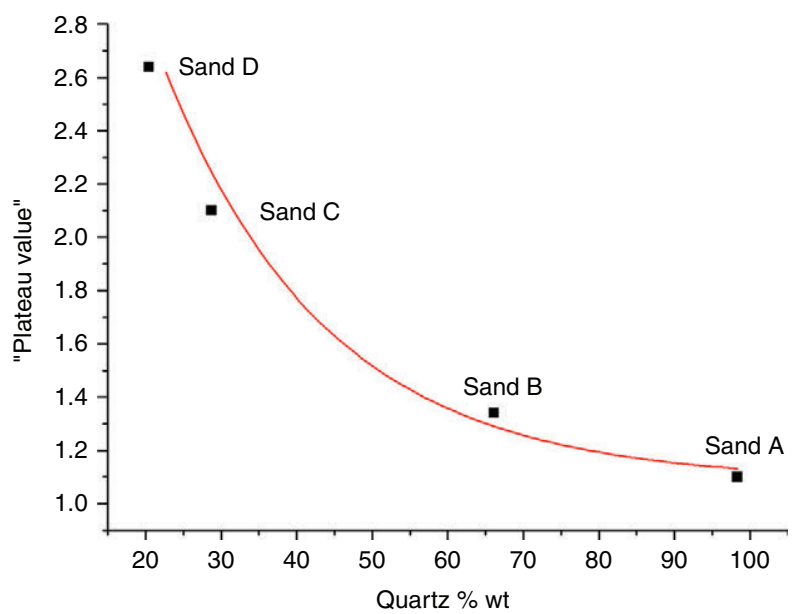

Figure 8. Quartz content versus PCE adsorption in four sands.

Table 8 reveals that quartz amount decrease substantially in fine fractions of sands C and D, whereas clay quantity increases specially in sand D, with valuable amounts of montmorillonite.

Nonetheless, while the correlation between quartz/clay content and adsorption (Figure 8) was high, it was not linear, a further indication that admixture consumption by these sands was the outcome of all the factors analysed.

However, it is important to note that PCE additive used in this paper has high side chains (see Table 5), which it is determinant in terms of lower intercalation in clays with respect to other PCE admixtures with shorter side chains more commonly used in practice.

In light of the findings, the factors found to affect the adsorption of admixture PCE mixed in water on sands of different composition included surface area, particle size distribution and the clay content. None of these factors was the sole determinant of the adsorption values found, however. Two further conclusions can also be drawn.

- In sands A and B, admixture adsorption was primarily related to the particle size distribution of the substrate.

- In sands C and D, the differences in adsorption values were attributed more to their composition than to their particle size distribution.

\subsection{Adsoption isotherms for sands in cement pore solution}

Figure 10 shows PCE adsorption on sands A, $\mathrm{B}, \mathrm{C}$ and $\mathrm{D}$ suspended in an cement pore solution, along with the respective plateau values.

As Figure 10 clearly shows, the adsorption values were $40-70 \%$ lower when the sands were suspended 

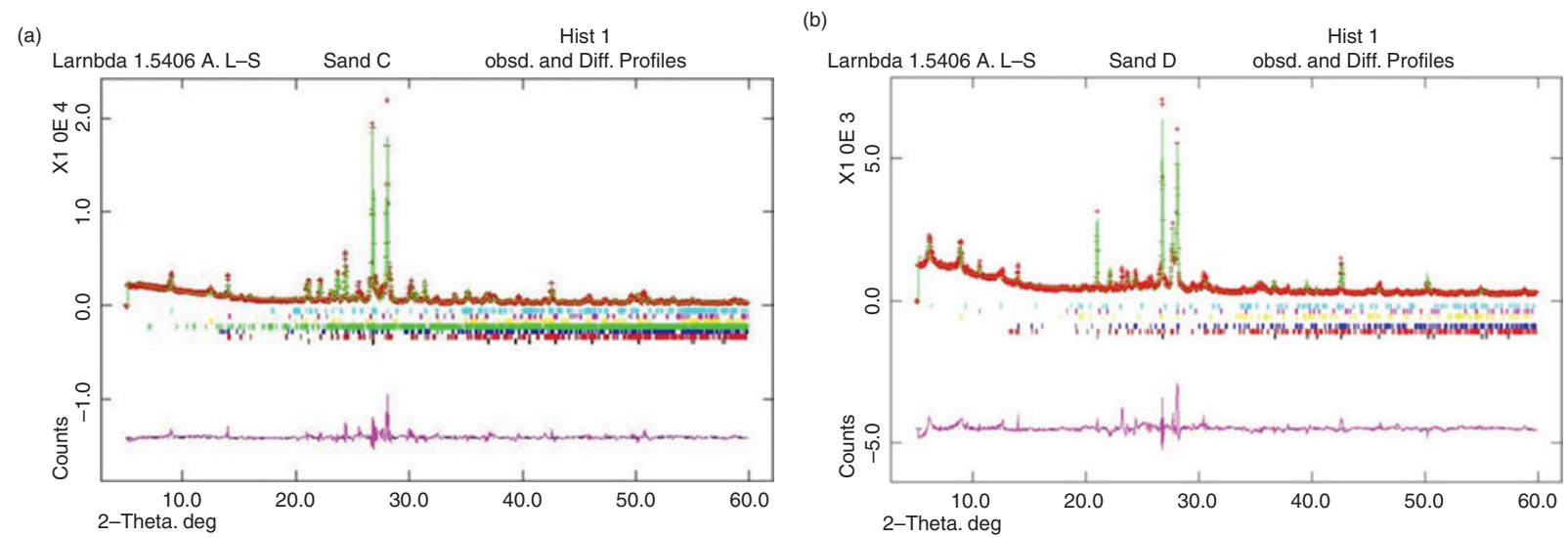

Figure 9. Rietveld analysis of fine fractions $(<125 \mathrm{~mm})$ of sands C and D.

TABLE 8. Quantitative mineralogical composition of fine fractions of sand $(\mathrm{wt} \%)$

\begin{tabular}{lcc}
\hline Mineralogical phase & C & D \\
\hline Quartz & 12.6 & 12.6 \\
Microcline & 19.5 & 23.6 \\
Albite & 46.0 & 38.1 \\
Anorthite & 12.0 & - \\
Rubidium silicoaluminate & 1.5 & - \\
Muscovite & 6.7 & - \\
Kaolinite & 1.8 & - \\
Chlorite & - & 6.1 \\
Phlogopite & & 11.5 \\
NaTiH $\left(\mathrm{PO}_{4}\right)_{2} \cdot \mathrm{H}_{2} \mathrm{O}$ & & 0.1 \\
Cordierite & & 1.7 \\
Montmorillonite & & 6.3 \\
\hline
\end{tabular}

in an cement pore solution than when they were suspended in water.

The zeta potential of $\mathrm{SiO}_{2}$ and more spcecifically of quartz in water is highly negative $(45,46)$. However, despite this negative zeta potential, PCE may absorb on to $\mathrm{SiO}_{2}$ particles via hydrogen bonds (46). Furthermore, the surface charge of clays in water at $\mathrm{pH}$ values of around 7 is also negative, ranging from -15 to $-30 \mathrm{mV}(24,47)$. As these were the conditions at which admixtures PCE and BNS suspended in water were adsorbed by the sands (Figures $4 \mathrm{a}$ and $4 \mathrm{~b}$ ), low adsorption values would be expected. The values found for admixture PCE, however, were 1.10, 1.34, 2.10 and $2.64 \mathrm{mg}$ polymer/g sand for sands A, B, C and $\mathrm{D}$, respectively. Despite the negative zeta potential, PCE may absorb on to sand particles. Given the large specific surface of the sand, physical adsorption may have also taken place (11). Lastly, as mentioned earlier, part of admixture PCE may have been interlayered in the clay structure, raising its consumption. For that reason, the higher the clay content in sand, the greater was the admixture PCE consumption observed.

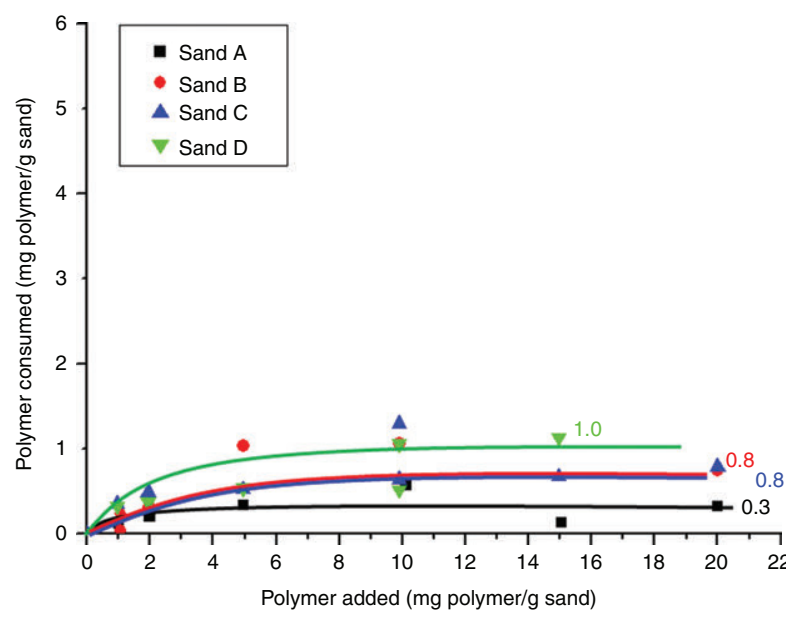

FIGURE 10. Isotherms for admixture PCE adsorption on sands suspended in an aqueous cement solution.

Nonetheless, adsorption declined drastically in the presence of the cement pore solution, despite expectations to the contrary. $\mathrm{Ca}^{2+}$ and $\mathrm{Na}^{+}$cations provided y cement pore solution may induced a change in $\mathrm{pH}$ to values of around 13. Under these conditions, the zeta potential in the clay and in the sand in general would be expected to move to more positive values, which would entail a rise in admixture PCE adsorption $(25,27)$. Moreover, Plank et al. (48) shown that silica fume $\left(\mathrm{SiO}_{2}\right)$ in model pore solution, adsorbed PCEs via $\mathrm{Ca}^{2+}$ ions adsorbed on the surface of initially negatively charged $\mathrm{SiO}_{2}$ particles.

The findings revealed the contrary, however. The explanation may lie in the fact that it was sand, not pure clay, that adsorbed the admixture and that the abrupt sag in adsorption would be attributable to the differences in ionic composition of liquid phase and changes in surface area. In addition to supplying cations, primarily $\mathrm{Ca}^{2+}$ and $\mathrm{Na}^{+}$, may induce changes in basal space of clays which would have a negative effect for admixtures intercalation (21). Further research is needed in this sense. 


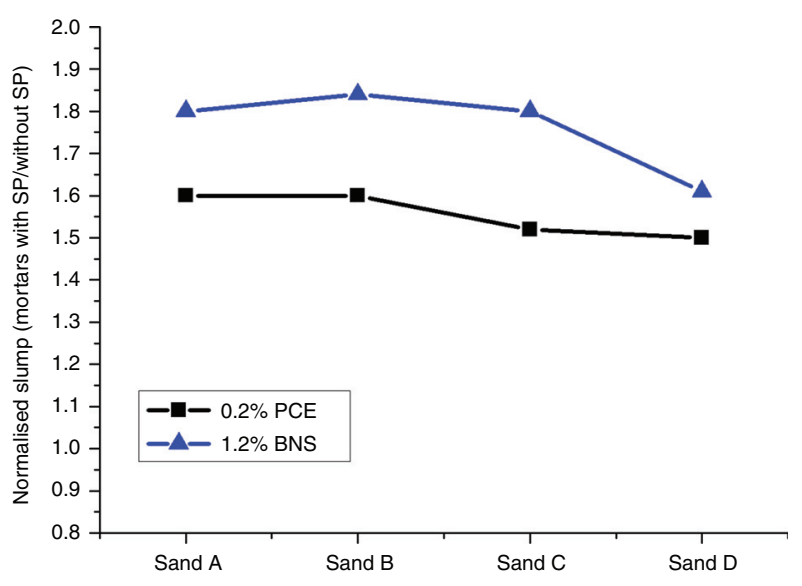

FIGURE 11. Increase in mortar fluidity in presence of superplasticizers.

\subsection{Effect of admixtures on fluidity of mortars}

Lastly, results for fluidity (normalised slump) changes in mortars without and with admixtures is shown in Figure 11.

As seen in Figure 11, the presence of both types of superplasticizers increase the fluidity of mortars regardless of the type of sand used, which is an indication that despite the adsorption / consumption of admixtures observed, the effect is not relevant in the flowability of mortars.

\section{CONCLUSIONS}

The main conclusions to be drawn from the present study are as follows.

1. Adsorption of conventional (BNS) and PCEbased superplasticisers on sands of different compositions suspended in water was confirmed to depend on a number of factors.

a. Admixture composition was shown to have an effect on adsorption, for BNS-based superplasticisers did not adsorb on sand, whereas the PCE-based admixtures exhibited variable adsorption depending on the composition of the substrate.

b. Generally speaking, the higher the specific surface and the finer the particle size distribution of the sands, the greater was admixture adsorption/consumption.

c. Lastly, sand chemical and mineralogical composition also played a role in adsorption. The higher the clay material and the lower the quartz content, the higher was admixture PC adsorption/consumption due to its interlayering in the clay.

2. In the presence of an aqueous cement solution, admixture PCE adsorption on sand fell drastically as a result of possible changes in ionic strength and sand's surface.
3. The fluidity of the mortars prepared with different sands is mainly affected by the the type of admixture and its dosage.

\section{ACKNOWLEDGEMENTS}

This study was funded by the MINECO under project BIA2013-47876-C2-1-P. The authors wish to thank P. Rivilla (IETcc-CSIC) for her support and collaboration in the tests conducted in connection with this study.

\section{REFERENCES}

1. Borralleras Mas, P. (2012). Criterios de selección del aditivo súper plastificantes Proceedings HAC. 3er Congreso Iberoamericano sobre Hormigón autocompactante, 2012. 55-66.

2. Spiratos, N.; Pagé, M.; Mailvaganam, N.P.; Malhotra, V.M.; Jolicoeur, C. (2006) Superplasticizers for concrete fundamentals, technology and practice. Handy Chemicals, Canada.

3. Gołaszewski, J. (2012) Influence of cement properties on new generation superplasticizers performance. Construc. Build. Mater., 35, 586-596. http://dx.doi.org/10.1016/j. conbuildmat.2012.04.070

4. Flatt, R.J.; Houst, Y.F. (2001) A simplified view on chemical effects perturbing the action of superplasticizers. Cem Concr Res., 31:1169-76. http://dx.doi.org/10.1016/ S0008-8846(01)00534-8

5. Yoshioka, K,; Tazawa, E.; Kawai, K.; Enohata, T. (2002) Adsorption characteristics of superplasticizers on cement component minerals. Cem. Concr. Res. 32, 1507-1513. http://dx.doi.org/10.1016/S0008-8846(02)00782-2

6. Plank, J.; Zhimin, D.; Keller, H.; Hössle, F.V.; Seidl, W. (2010) Fundamental mechanisms for polycarboxylate intercalation into C3A hydrate phases and the role of sulfate present in cement. Cem. Concr. Res. 40, 45-57. http:// dx.doi.org/10.1016/j.cemconres.2009.08.013

7. Alonso, M.M.; Palacios, M.; Puertas, F. (2013) Effect of Polycarboxylate-Ether Admixtures on Calcium Aluminate Cement Pastes. Part 1: Compatibility Studies. Ind. Eng. Chem. Res. 52, 17323-17329. http://dx.doi.org/10.1021/ie401615t

8. Zingg, A.; Winnefeld, F.; Holzer, L.; Pakusch, J.; Becker, S.; Figi, R.; Gauckler, L. (2009) Interaction of polycarboxylate-based superplasticizers with cements containing different $\mathrm{C}_{3} \mathrm{~A}$ amounts. Cem. Concr. Comp. 31[3], 153-162. http://dx.doi.org/10.1016/j.cemconcomp.2009.01.005

9. Alonso, M.M, Puertas, F. ( 2015) Adsorption of PCE and PNS superplasticisers on cubic and orthorhombic $\mathrm{C}_{3} \mathrm{~A}$. Effect of sulfate. Construc. Build. Mat. 78, 324-332. http:// dx.doi.org/10.1016/j.conbuildmat.2014.12.050

10. Alonso, M.M.; Palacios, M.; Puertas, F. Compatibility between polycarboxylate based admixtures and blendedcement pastes. Cem. Concr. Comp. 35, 151-62. http:// dx.doi.org/10.1016/j.cemconcomp.2012.08.020

11. Burgos-Montes, O.; Palacios, M.; Rivilla, P.; Puertas, F. (2012) Compatibility between superplasticizer admixtures and cements with mineral additions. Construc. Build. Mat. 31, 300-309. http://dx.doi.org/10.1016/j.conbuildmat.2011.12.092

12. Puertas, F.; Santos, H.; Palacios, M.; Martínez-Ramírez, S. (2005) Polycarboxylate superplasticizer admixtures: effect on hydration; microstructure and rheological behaviour in cement pastes. Adv. Cem. Res. 17, 77-89. http://dx.doi. org/10.1680/adcr.2005.17.2.77

13. Stroh, J.; Schlegel, M.C.; Schmidt, W.; Nguyen Thi, Y.; Meng, B.; Emmerling, F. (2016) Time-resolved in situ investigation of Portland cement hydration influenced by chemical admixtures. Construc. Build. Mat. 106, 8-26. http:// dx.doi.org/10.1016/j.conbuildmat.2015.12.097

14. Zeghichi, L.; Benghazi, Z.; Baali, L. (2014) The effect of the kind of sands and additions on the mechanical behaviour of S.C.C. Physics Procedia. 55, 485-492. 
15. Viacava, I.R.; Cavalaro, SHP.; Sensale, GR.; Aguado, A. (2012) Directrices de dosificación para HAC de baja y media resistencia. Proceedings HAC. $3^{\text {er }}$ Congreso Iberoamericano sobre Hormigón autocompactante. 35-44.

16. Westerholm, M.; Lagerblad, B.; Silfwerbrand, J.; Forssberg, E. (2008) Influence of fine aggregate characteristics on the rheological properties of mortars. Cem. Concr. Comp. 30, $274-282$. http://dx.doi.org/10.1016/j.cemconcomp. 2007. 08.008

17. Fernández-Ledesma, E.; Jiménez, J.R, Ayuso, J.; Corinaldesi.; V.; Iglesias-Godino.; F.J. (2016) A proposal for the maximum use of recycled concrete sand in masonry mortar design. Mater. Construcc. 66 [321], e075. http:// dx.doi.org/10.3989/mc.2016.08414

18. Saiz-Martínez, P.; González-Cortina, M.; FernándezMartínez, F. (2015) Characterization and influence of fine recycled aggregates on masonry mortars properties. Mater. Construcc. 65 [319] e058. http://dx.doi.org/10.3989/ mc.2015.06014

19. Fernandes, V.A.; Purnell, P.; Still, G.T.; Thomas, T.H. (2007) The effect of clay content in sands used for cementitious materials in developing countries. Cem. Concr. Res. 37, 751-758. http://dx.doi.org/10.1016/j.cemconres.2006.10.016

20. Lei, L.; Plank, J. (2014) A study on the impact of different clay minerals on the dispersing force of conventional and modified vinyl ether based polycarboxylate superplasticizers. Cem. Concr. Res. 60, 1-10. http://dx.doi.org/10.1016/j. cemconres.2014.02.009

21. Ait-Akbour, R.; Boustingorry, P.; Leroux, F.; Leising, F.; Taviot-Guého, C. (2015) Adsorption of PolyCarboxylate Poly(ethylene glycol) (PCP) esters on Montmorillonite $(\mathrm{Mmt})$ : Effect of exchangeable cations $\left(\mathrm{Na}^{+} ; \mathrm{Mg}^{2+}\right.$ and $\mathrm{Ca}^{2+}$ ) and PCP molecular structure. J. Colloid. Interf. Sci. 437, 227-234. http://dx.doi.org/10.1016/j.jcis.2014.09.027

22. Barton, C.D.; Karathanasis, A.D. (2002) Clay minerlas. Encyclopedia of Soil Science, 187-192.

23. Atarashi, D.; Sakai, E.; Obinata, R.; Daimon, M. (2004) Interactions between Superplasticizers and Clay Minerals. Cem. Sci. Concr. Technol. 58, 387-392.

24. Ng, G.B.S. (2013) Interactions of Polycarboxylate based Superplasticizers with Montmorillonite Clay in Portland Cement and with Calcium Aluminate Cement. PhD thesis Technische Universität München.

25. Plank, J.; Sakai, E.; Miao, C.W.; Hong, J.X. (2015) Chemical admixtures. Chemistry.; applications and their impact on concrete microstructure and durability. Cem. Concr. Res. 78, 81-99. http://dx.doi.org/10.1016/j. cemconres.2015.05.016

26. Lei, L.; Plank, J. (2012) A concept for a polycarboxylate superplasticizer possesing enhanced clay tolerance. Cem. Concr. Res. 42, 1299-1306. http://dx.doi. org/10.1016/j.cemconres.2012.07.001

27. Ng, S.; Plank, J. (2012) Interaction mechanisms between Na montmorillonite clay and MPEG-based polycarboxylate superplasticizers. Cem. Concr. Res. 42, 847-854. http:// dx.doi.org/10.1016/j.cemconres.2012.03.005

28. Giaccio, G.; Tobes, J.M.; Zerbino, R. (2012) Influencia de la fracción fina de la arena en el diseño de HAC. Proceedings HAC. 3er Congreso Iberoamericano sobre Hormigón autocompactante. 99-108.

29. Roncero, J.; Gettu, R.; Gomes, P.C.C.; Agulló, L. (1999) Study of the flow behaviour of superplasticized cement paste systems and its influence on the properties of fresh concrete "High performance concrete. Research to practice Procc. ACi Chicago.; ACI SP-189. American Concrete Institute. 273-294.

30. UNE 80230:1999 Methods of testing cement. Chemical analysis. Alternative methods.

31. Ruiz SantaQuiteria, C. (2013) Materias primas alternativas para el desarrollo de nuevos cementos: activación alcalina de vidrios silicoaluminosos. PhD thesis UAM.; Madrid. Spain.

32. Tironi, A.; Trezza, M.A.; Scian, A.N.; Irassar, E.F. (2012) Kaolinitic calcined clays: Factors affecting its performance as pozzolans. Const. Build. Mat. 28, 276-281. http://dx.doi. org/10.1016/j.conbuildmat.2011.08.064

33. Van der Marel, H.W.; Beutelspacher, H. (1976) Atlas of infrared spectroscopy of clay minerals and their admixtures. Ed. Elsevier.

34. Handbook of analytical techniques in concrete science and technology. (1999) Principles, Techniques, and Applications. Edited by V. S. Ramachandran and James J. Beaudoin. Institute for Research in Construction National Research Council Canada.

35. EN 1097-6:2001/A1:2006. (2001) Tests for mechanical and physical properties of aggregates - Part 6: Determination of particle density and water absorption.

36. EN 480-8. (1997) Admixtures for concrete.; mortar and grout. test methods. Part 8: Determination of the conventional dry material content.

37. Houst, Y.F.; Bowen, P.; Perche, F.; Kauppi, A.; Borget, P.; Galmiche, L.; Le Meins, J.F.; Lafuma, F.; Flatt, R.; Schober, I.; Banfill, P.F.G.; Swift, D.S.; Myrvold, B.O.; Petersen, B.G.; Reknes, K. (2008) Design and Function of Novel Superplasticizers for More Durable High Performance Concrete(Superplast Project). Cem. Concr. Res. 38, 1197-1209. http://dx.doi.org/10.1016/j.cemconres.2008.04.007

38. Perche, F. (2004) Adsorption de polycarboxylates et de lignosulfonates sur poudre modèle et ciments. PhD thesis EPFL.; Lausanne, Switzerland.

39. Alonso, M.M. (2011) Comportamiento y compatibilidad de cementos y aditivos superplastificantes basados en carboxilatos. Efecto de la naturaleza de los cementos y estructura de los aditivos. PhD thesis UAM.; Madrid, Spain.

40. UNE-EN 196-1: 2005. (2005) Methods of testing cement Part 1: Determination of strength.

41. UNE-EN 1015-3:2000. (2000) Methods of test for mortar for masonry - Part 3: Determination of consistence of fresh mortar (by flow table).

42. Ramachandran, V.S.; Malhotra, V.M.; Jolicoeur, C.; Spiratos, N. Superplasticizers: properties and applications in concrete (1998) CANMET Ed. Canada.

43. Zhang, Y.; Kong, X. (2015) Correlations of the dispersing capability of NSF and PCE types of superplasticizer and their impacts on cement hydration with the adsorption in fresh cement pastes. Cem. Concr. Res. 69, 1-9. http:// dx.doi.org/10.1016/j.cemconres.2014.11.009

44. Vikan, H.; Jutnes, H.; Winnefeld, F.; Figi, R. (2007) Correlating cement characyteristics with rheology of paste. Cem. Concr. Res. 37, 1502-1511. http://dx.doi. org/10.1016/j.cemconres.2007.08.011

45. Cuihua Tanga; Jianxi Zhua; Zhaohui Li; Runliang Zhua; Qing Zhoua; Jingming Wei; Hongping Hea; Qi Tao. (2015) Surface chemistry and reactivity of $\mathrm{SiO}_{2}$ polymorphs: A comparative study on -quartz and -cristobalite. Applied Surface Science, 55, 1161-1167.; http://dx.doi. org/10.1016/j.apsusc. 2015.07.214

46. Hommer, H. (2009) Interaction of polycarboxylate ether with silica fume. J. Europ. Cer. Soc. 29, 1847-1853. http:// dx.doi.org/10.1016/j.jeurceramsoc.2008.12.017

47. Jong-Yeop, K.; Sansalone, J.J. (2008) Zeta potential of clay-size particles in urban rainfall-runoff during hydrologic transport. Journal of Hydrology, 356, 163-173 http://dx.doi.org/10.1016/j.jhydrol.2008. 04.006

48. Schröfl, Ch.; Gruber, M.; Plank, J. (2012) Preferential Adsorption of Polycarboxylate Superplasticizers on Cement and Silica Fume in Ultra-High Performance Concrete (UHPC). Cem. Concr. Res., 42, 1401-1408. http://dx.doi.org/10.1016/j.cemconres.2012.08.013 